\title{
Analiza możliwości wdrożenia szpitalnej oceny technologii medycznych (HB-HTA) na podstawie modelu z koordynująca rolą niezależnej oryanizacji zewnętrznej
}

Tomasz Bochenek ${ }^{1}$ (i) htpps///rcid.-orgy0000-0001-9915-7267

Alicja Sobczak ${ }^{2}$ (ํ) htpps://orid.orgy0000-0002-3069-1098

Dariusz Szplit ${ }^{3}$

Agata Smoleń ${ }^{4}$

Anna Tybińkowska ${ }^{5,3}$

Michał F. Farkowski ${ }^{6}$

\footnotetext{
${ }^{1}$ Zakład Badań nad Żywieniem i Lekami, Instytut Zdrowia Publicznego Wydział Nauk o Zdrowiu Uniwersytet Jagielloński Collegium Medicum

${ }^{2}$ Uniwersytet Warszawski, pracownik emerytowany

${ }^{3}$ Zespół Oceny i Wdrożeń Technologii Medycznych, Uniwersyteckie Centrum Kliniczne, Gdańsk

${ }^{4}$ Dział Programów Badawczych, Narodowy Instytut Kardiologii Stefana kardynała Wyszyńskiego, Państwowy Instytut Badawczy, Warszawa

${ }^{5}$ Katedra Marketingu, Wydział Zarządzania i Ekonomii, Politechnika Gdańska

${ }^{6}$ II Klinika Zaburzeń Rytmu Serca, Narodowy Instytut Kardiologii Stefana kardynała Wyszyńskiego, Państwowy Instytut Badawczy, Warszawa
}

Adres do korespondencji: Tomasz Bochenek, Zakład Badań nad Żywieniem i Lekami, Instytut Zdrowia Publicznego Wydział Nauk o Zdrowiu UJ CM, ul. Skawińska 8, 31-066 Kraków, t.bochenek@uj.edu.pl

\section{Abstract}

Implementation of Hospital-Based Health Technology Assessment (HB-HTA) with the coordinating role of independent external organization

Hospital-Based Health Technology Assessment (HB-HTA) aims to support local decision-making on investing in new health technologies limited to the hospital level. The goal of this study was to prepare and present the strategic functional model of HB-HTA in Poland with coordinating role of an organization labelled as the independent external organization (NOZ). The stakeholders of the HB-HTA process were identified, together with their interests and relations among them, as well as the goals and consequences of health policy in area of implementation of HB-HTA in Poland. The conduct of HB-HTA process was presented, the tasks foreseen for NOZ, its possible organizational forms, barriers, and possibilities of development; as well as the overall capacity of this organization in area of HB-HTA. It is foreseen that the development of HB-HTA in Poland based on NOZ should take place within a positively inclined environment, having a generally positive impact on the health care system, positive prognoses, and opportunities for implementation of HB-HTAh

Key words: health care management, health technology, Health Technology Assessment, Hospital-Based Health Technology Assessment HB-HTA, hospital, hospital treatment

Stowa kluczowe: HB-HTA, lecznictwo szpitalne, ocena technologii medycznych, szpitalna ocena technologii medycznych, szpital, technologia medyczna, zarzadzanie ochrona zulrowia 


\section{Wprowadzenie}

Rosnąca liczba, ale również koszt, nowych technologii medycznych wprowadzanych na rynek każdego roku wymuszają precyzyjną ocenę jakości i opłacalności tych innowacji. Ocena technologii medycznych (Health Technology Assessment, HTA) jest interdyscyplinarnym, usystematyzowanym, formalnym procesem oceny wartości technologii medycznej za pomocą jasno sprecyzowanych metod, który można przeprowadzić na różnych etapach cyklu życia danej technologii. Podstawowym celem HTA jest dostarczanie informacji dla podmiotów decyzyjnych celem promowania sprawiedliwego i efektywnego systemu ochrony zdrowia [1].

HTA jako narzędzie oceny nowych technologii medycznych może być wykorzystywane również na poziomie lokalnym. Szpitalna ocena technologii medycznych (Hospital-Based Health Technology Assessment, HB-HTA) ma na celu wsparcie lokalnej decyzji o zainwestowaniu w nową technologię medyczną, ograniczonej do poziomu pojedynczego szpitala [2]. Podstawowym narzędziem HB-HTA jest raport HB-HTA. W związku ze specyficzną perspektywą oraz zasięgiem konsekwencji podjętych decyzji (poziom krajowy a poziom szpitala) HB-HTA wymaga nieco odmiennego podejścia metodycznego niż HTA [2, 3]. Przede wszystkim specyficzna perspektywa, z której opracowywany jest raport HB-HTA, wymusza często stosowanie jako komparatora raczej technologii medycznej stosowanej lokalnie niż „złotego standardu” klinicznego (właściwego bardziej dla raportu HTA niebędącego HB-HTA). Ponadto raport HB-HTA adresowany jest do kadry menadżerskiej szpitala, bardziej zainteresowanej bezpośrednimi kosztami implementacji nowej technologii niż wyrafinowanymi wskaźnikami farmakoekonomicznymi. Sam raport HB-HTA zwykle powstaje w szpitalu i przygotowywany jest przez pracowników danej jednostki, nie zaś ekspertów specjalizujących się w HTA. Przekłada się to bezpośrednio na krótsze terminy przygotowania raportu oraz mniej sformalizowane standardy przeprowadzania takich analiz, a także na niższe koszty przygotowania raportu.

Raporty HB-HTA są wartościowymi opracowaniami wspierającymi kadrę menadżerską w podejmowaniu decyzji o inwestycjach $w$ nowe technologie medyczne $[2,4,5]$. HB-HTA nie ma jednolitej formuły i w zależności od kraju przyjmuje różne postacie [6]. Już sam proces sformalizowania i uregulowań prawnych działania HB-HTA różni się znacząco pomiędzy krajami. Zasadniczo są to mniej lub bardziej zdecentralizowane, nieformalne sieci powiązań pomiędzy lokalnymi jednostkami HB-HTA, relatywnie rzadko związane bezpośrednio z urzędami centralnymi. Powiązania takie podtrzymywane są zwykle celem wymiany informacji (w tym raportów HB-HTA), szkoleń, ale również standaryzacji i ewaluacji procesu HB-HTA na poziomie krajowym [6]. Na poziomie szpitalnym komórki HB-HTA mogą przyjmować różne formy, w zależności od zaawansowania procesu HB-HTA w danym kraju: od prostych niezależnych grup do specjalistycznych zintegrowanych jednostek HB-HTA. Zazwyczaj wyższy poziom organizacji jednostki HB-HTA wiąże się z wyższym stopniem specjalizacji ich pracowników, ale również rosnącym poziomem formalizacji i standaryzacji wewnętrznych procedur.

W ramach przeglądu systematycznego nie wskazano jednego optymalnego modelu funkcjonalnego HB-HTA, gotowego do implementacji w Polsce [6]. W związku z tym konsorcjum realizujące projekt naukowo-badawczy „Wdrożenie systemu Hospital-Based HTA (HB-HTA) - Szpitalnej Oceny Innowacyjnych Technologii Medycznych", finansowany przez Narodowe Centrum Badań i Rozwoju w ramach Strategicznego Programu Badań Naukowych i Prac Rozwojowych „Społeczny i gospodarczy rozwój Polski w warunkach globalizujących się rynków" GOSPOSTRATEG, zadecydowało o potrzebie przygotowania propozycji kilku różnych modeli funkcjonalnych HB-HTA możliwych do implementacji w Polsce, a następnie wyboru modelu optymalnego dla warunków polskich.

Celem niniejszego opracowania było przygotowanie strategicznego modelu funkcjonalnego HB-HTA w Polsce z koordynującą rolą organizacji, określonej jako niezależna organizacja zewnętrzna (dalej: NOZ).

\section{Interesarilisze procesu HB-HTa i cele polityki zulowotnej W obszarze wulazania HB-HTA}

W modelu wdrażania HB-HTA w Polsce, w którym kluczową rolę odegrałaby NOZ, zostało zidentyfikowanych łącznie 25 interesariuszy (kluczowych podmiotów), którzy dla ułatwienia opisu i charakterystyki zostali podzieleni na 9 grup (tabela 1 ).

Do pierwszej grupy zaliczono organizacje będące instytucjami rządowymi lub powiązanymi $\mathrm{z}$ administracją rządową. Odgrywają one zróżnicowaną rolę w procesie oceny, rekomendowania i zatwierdzania technologii medycznych wdrażanych na poziomie szpitali. Rola ta jest związana przede wszystkim z gromadzeniem danych, zbieranych z całego systemu ochrony zdrowia, i z możliwością określania standardów metodologicznych. Interesariusze wymienieni w tej grupie mają istotny wpływ na określanie zasad funkcjonowania szpitali, realizacji i finansowania świadczeń zdrowotnych ze środków publicznych oraz alokacji środków publicznych przeznaczanych na zakup szpitalnych technologii medycznych. Ich wpływ na realizację celów polityki wdrażania HB-HTA w Polsce, a także na ogólne ramy procesu HB-HTA jest bardzo duży, zarówno na poziomie strategicznym polityki zdrowotnej, jak i na poziomie operacyjnym ${ }^{1}$.

W drugiej grupie kluczowych podmiotów znalazły się organizacje związane $\mathrm{z}$ organami jednostek samorządu terytorialnego. Interesariusze $\mathrm{z}$ tej grupy odgrywają kluczową rolę w podejmowaniu decyzji o alokacji środków przeznaczanych na zakup szpitalnych technologii medycznych, gromadzą dane niezbędne przy określaniu efektywności kosztowej tych technologii, współkształtują lokalną politykę zdrowotną oraz funkcjonują na poziomie operacyjnym tej polityki. W praktyce poprzez swoje decyzje operacyjne mogą ułatwiać bądź utrudniać wdrażanie polityki HB-HTA, zaś rzadziej 
Tabela 1. Zbiorcze zestawienie kluczowych podmiotów (interesariuszy) zidentyfikowanych $\mathrm{w}$ modelu wdrażania HB-HTA z udzialem NOZ

\begin{tabular}{|c|l|}
\hline Lp. & \multicolumn{1}{|c|}{ Nazwa grupy interesariuszy } \\
\hline 1. & $\begin{array}{l}\text { Organizacje będące instytucjami rządowymi lub powiązanymi } \\
\text { z administracją rządową: } \\
\text { Ministerstwo Zdrowia (MZ); Agencja Oceny Technologii } \\
\text { Medycznych i Taryfikacji (AOTMIT); Agencja Badań Medycz- } \\
\text { nych (ABM); Narodowy Fundusz Zdrowia (NFZ) Centrala, } \\
\text { oddziały wojewódzkie NFZ, urzędy wojewódzkie (wydziały } \\
\text { do spraw polityki społecznej i zdrowia) }\end{array}$ \\
\hline 2. & $\begin{array}{l}\text { Organizacje związane z organami jednostek samorządu } \\
\text { terytorialnego: } \\
\text { urzędy marszałkowskie, starostwa powiatowe }\end{array}$ \\
\hline 3. & $\begin{array}{l}\text { Interesariusze związani ze środowiskiem pacjentów: } \\
\text { organizacje pacjenckie; pacjenci, którzy aktywnie walczą } \\
\text { o swoje prawa }\end{array}$ \\
\hline 4. & $\begin{array}{l}\text { Podmioty silnie powiązane z naukowymi, metodologicznymi } \\
\text { i dydaktycznymi aspektami HB-HTA: } \\
\text { szkoły wyższe, ośrodki akademickie, placówki naukowo- } \\
\text {-badawcze, ośrodki doradczo-konsultingowe }\end{array}$ \\
\hline 5. & $\begin{array}{l}\text { Szpitale: } \\
\text { szpitale publiczne, dla których podmiotem tworzącym są: } \\
\text { województwo, gmina lub powiat; uczelnia; minister (forma } \\
\text { działalności - samodzielny publiczny zakład opieki zdrowot- } \\
\text { nej lub jednostka budżetowa); szpitale będące instytutami } \\
\text { naukowo-badawczymi }\end{array}$ \\
\hline 6. & $\begin{array}{l}\text { Profesjonaliści sektora opieki zdrowotnej: } \\
\text { klinicyści, konsultanci krajowi i wojewódzcy, kadra zarządza- } \\
\text { jąca o wysokiej skłonności do innowacji, kadra zarządzająca } \\
\text { o niskiej skłonności do innowacji }\end{array}$ \\
\hline 7. & $\begin{array}{l}\text { Właściciele (udziałowcy i akcjonariusze) szpitali niepublicz- } \\
\text { nych (spółki prawa handlowego, głównie kapitałowe) }\end{array}$ \\
\hline 8. & $\begin{array}{l}\text { Firmy sektora innowacyjnych technologii medycznych, w tym } \\
\text { producenci i sprzedawcy tych technologii }\end{array}$ \\
\hline media tradycyjne (specjalistyczne i ogólne), media \\
społecznościowe
\end{tabular}

Źródto: opracowanie własne.

wytyczają cele w tym obszarze i monitorują w sposób systematyczny ich realizację.

W trzeciej grupie zidentyfikowano interesariuszy związanych ze środowiskiem pacjentów. Nie posiadają oni bezpośredniego wpływu na podejmowanie decyzji o alokacji środków finansowych na zakup szpitalnych technologii medycznych. Interesariusze $\mathrm{z}$ tej grupy mogą funkcjonować na obu poziomach (strategicznym i operacyjnym) polityki zdrowotnej w obszarze wdrażania HB-HTA w Polsce. Ich wpływ na realizację celów polityki zdrowotnej w obszarze HB-HTA jest kluczowy, chociaż pośredni.

Czwartą grupę interesariuszy stanowią podmioty, których wspólną cechę stanowi silne powiązanie z naukowymi, metodologicznymi i dydaktycznymi aspektami HB-HTA, stanowiącymi zaplecze eksperckie (naukowo-badawcze) dla rozwoju HB-HTA w Polsce. Ich wpływ na różne aspekty oceny i wdrażania technologii medycznych jest pośredni, niekiedy duży i znacznie wyprzedzający czasowo decyzje na poziomie strategicznym, jak też operacyjnym polityki zdrowotnej w obszarze wdrażania HB-HTA w Polsce.
Piątą grupę kluczowych interesariuszy stanowią szpitale, klasyfikowane według rodzaju oraz podmiotu tworzącego. Ich status formalny, zależność od podmiotu tworzącego, poziom referencyjny, zakres i terytorialny zasięg działania warunkują nastawienie na zmiany szpitalnych technologii medycznych, rozwój własnych służb (profesjonalnych zespołów) HB-HTA oraz decyzje o wdrażaniu nowych technologii. Dostarczając kluczowych danych o wdrożonych już szpitalnych technologiach medycznych oraz szpitalnym środowisku wdrażania nowych technologii, interesariusze znajdujący się w tej grupie mają bardzo ważne znaczenie - w odniesieniu do klinicznych, ekonomicznych, finansowych i organizacyjnych aspektów HB-HTA, a także w zakresie określania efektywności kosztowej technologii medycznych. Jest to również środowisko, dla którego lub w którym bezpośrednio podejmowane są decyzje o zakupie konkretnych szpitalnych technologii medycznych, w tym właśnie środowisku wdrażanych.

Interesariusze $\mathrm{z}$ grupy szpitali funkcjonują na poziomie operacyjnym polityki zdrowotnej w obszarze wdrażania HB-HTA w Polsce, realizując tę politykę i nadając jej realny kształt. Niektóre spośród szpitali mogą mieć wpływ na tę szczegółową politykę zdrowotną także na poziomie strategicznym, przy współudziale innych interesariuszy. Wpływ interesariuszy z tej grupy na realizację celów polityki zdrowotnej jest kluczowy, chociaż w większości przypadków pośredni. W modelu wdrażania HB-HTA z udziałem NOZ przewiduje się, że wsparcie szpitali dla związanej z tym wdrażaniem polityki zdrowotnej byłoby zróżnicowane. Ze względu na największe prawdopodobieństwo zainteresowania nowymi technologiami szpitalnymi i największe doświadczenie wsparcie to byłoby najsilniejsze ze strony szpitali specjalistycznych, należących do wyższego stopnia referencyjnego (szpitale z uczelnią jako podmiotem tworzącym, szpitale posiadające status instytutów naukowo-badawczych).

W szóstej grupie interesariuszy znaleźli się wybrani profesjonaliści sektora opieki zdrowotnej, generujący dane do analiz szpitalnych technologii medycznych oraz formułujący opinie i oceny. W ten sposób uczestniczą oni w podejmowaniu decyzji o alokacji środków finansowych na zakup technologii, funkcjonując na wszystkich poziomach polityki zdrowotnej $\mathrm{w}$ obszarze wdrażania HB-HTA w Polsce. Ich możliwości wpływu na realizację celów tej polityki są kluczowe.

Siódmą wyodrębnioną grupą interesariuszy są właściciele szpitali niepublicznych (głównie spółek kapitałowych). Rola tych interesariuszy polega na podejmowaniu decyzji o alokacji środków finansowych na szpitalne technologie medyczne. Tę grupę interesariuszy należy postrzegać jako mającą istotny pośredni wpływ na wdrażanie HB-HTA w Polsce.

W kolejnej, ósmej, grupie zawarto firmy sektora innowacyjnych technologii medycznych, w tym producentów i sprzedawców tych technologii, dostarczających bezpośrednio szpitalne technologie medyczne. Rola tej grupy w określaniu efektywności kosztowej technologii jest duża. Grupa ta nie podejmuje decyzji o alokacji środków finansowych przeznaczanych 
w systemie ochrony zdrowia na użytkowanie technologii medycznych. Podmioty znajdujące się w tej grupie funkcjonują na poziomie operacyjnym polityki zdrowotnej w obszarze wdrażania HB-HTA w Polsce, zaś ich możliwości wpływu na realizację celów tej polityki są kluczowe, bezpośrednie oraz pośrednie.

Ostatnią, dziewiąta, grupe kluczowych podmiotów stanowią środki masowego przekazu, zaś wśród nich media tradycyjne (specjalistyczne i ogólne) oraz społecznościowe. Nie określają one efektywności kosztowej technologii medycznych, zaś ich wpływ na decyzje o alokacji środków finansowych na technologie może być zróżnicowany (jest on pośredni). Interesariusze z tej grupy funkcjonują na wszystkich poziomach polityki zdrowotnej w obszarze wdrażania HB-HTA w Polsce (na poziomie strategicznym - w sytuacji celowego angażowania środków masowego przekazu lub w przypadku technologii medycznych, które mogą wzbudzać szczególne zainteresowanie opinii publicznej). Ich możliwości wpływu na realizację celów tej polityki są kluczowe, zarówno bezpośrednie, jak też pośrednie.

Zidentyfikowano sześć celów polityki zdrowotnej w obszarze wdrażania HB-HTA w Polsce, w modelu opartym na istnieniu NOZ (tabela 2). Powinny być one związane z popularyzacją nowej dziedziny analitycznej w sektorze ochrony zdrowia, budowaniem potencjału (kompetencji) szpitali w zakresie HB-HTA i upowszechnianiem wiedzy oraz dobrych praktyk $\mathrm{z}$ tego zakresu, a także wszechstronnym wspomaganiem innych interesariuszy, takich jak: instytucje publiczne, organizacje społeczne, przedsiębiorcy i zróżnicowane środowiska profesjonalistów. Opisywany model wdrażania HB-HTA oparty jest na kluczowej roli organizacji określonej mianem NOZ, tak więc pomyślne jego wdrożenie zależne jest od sukcesu rynkowego i stopniowego rozwoju tej instytucji. Cele rozwoju opisywanego modelu i związanej z nim polityki zdrowotnej są zbieżne z żywotnymi celami NOZ jako podmiotu, który musi rozwinąć się, podtrzymać swoje funkcjonowanie i przetrwać w systemie ochrony zdrowia. Sukcesy odnoszone przez NOZ będą współgrać z sukcesami polityki rozwoju HB-HTA w Polsce, co stanowi bardzo korzystną przesłankę dla korzystnego rozwoju opisywanego modelu wdrażania HB-HTA w Polsce.

\section{Konsekwencje polityki wdrażania HB-HTA i interesy poszczególnych interesariluszy}

Polityka wdrażania HB-HTA w Polsce, opierająca się na NOZ, miałaby duże konsekwencje praktycznie dla wszystkich interesariuszy z grup związanych ze szpitalami, jak również dla właścicieli (udziałowców i akcjonariuszy) szpitali niepublicznych. W grupie szpitali konsekwencje te wiązałyby się głównie z uzyskaniem w postaci NOZ nowego sojusznika i partnera, dostarczającego bardzo potrzebnego szpitalom produktu, jakim są raporty $\mathrm{z}$ analiz HB-HTA, lub oferującego pomoc we wdrażaniu nowych szpitalnych technologii medycznych. Podobnie właściciele szpitali niepublicznych powinni skorzystać z możliwości profesjonalnego wsparcia udzielanego przez NOZ w zakresie analiz HB-HTA. Długofalowo powinno to przynieść wzrost rentowności ze stosowania nowych technologii

Tabela 2. Cele polityki zdrowotnej w modelu opartym na NOZ i mechanizmy jej wdrażania

\begin{tabular}{|c|c|}
\hline Cel polityki zdrowotnej & Mechanizm wdrażania \\
\hline $\begin{array}{l}\text { Upowszechnienie szpitalnej oceny technologii me- } \\
\text { dycznych (HB-HTA) w polskim systemie ochrony } \\
\text { zdrowia i zwiększenie potencjału szpitali w zakresie } \\
\text { HB-HTA }\end{array}$ & $\begin{array}{l}\text { Wdrożenie racjonalnego modelu przeprowadzania analiz w zakresie HB-HTA oraz } \\
\text { zbudowanie oferty przydatnych usług doradczych dla szpitali w zakresie opracowania } \\
\text { i oceny raportów HB-HTA, a także dostarczenie pomocy we wdrażaniu nowych techno- } \\
\text { logii w szpitalach i wyszukiwaniu źródeł ich finansowania }\end{array}$ \\
\hline $\begin{array}{l}\text { Wspomaganie inicjatyw organizacji społecznych, } \\
\text { w tym organizacji reprezentujących pacjentów, w za- } \\
\text { kresie korzystania z HB-HTA }\end{array}$ & $\begin{array}{l}\text { Zbudowanie oferty przydatnych usług doradczych w zakresie opracowywania raportów } \\
\text { HB-HTA, recenzje raportów, określanie warunków wdrożeń technologii przez szpitale }\end{array}$ \\
\hline $\begin{array}{l}\text { Wspomaganie przedsiębiorców (przemysł me- } \\
\text { dyczny, w tym zajmujący się wyrobami medycz- } \\
\text { nymi) działających na rynkach nowych technologii } \\
\text { medycznych w zakresie dostosowania technologii } \\
\text { do potrzeb systemu ochrony zdrowia }\end{array}$ & $\begin{array}{l}\text { Zbudowanie oferty przydatnych usług doradczych - raporty HB-HTA, recenzje raportów, } \\
\text { określenie warunków wdrożenia przez szpitale, opiniowanie oferty rynkowej i doradz- } \\
\text { two w zakresie możliwości jej wdrożenia i modyfikacji przez szpitale }\end{array}$ \\
\hline $\begin{array}{l}\text { Wspomaganie instytucji publicznych w zakresie } \\
\text { rozwoju HB-HTA }\end{array}$ & $\begin{array}{l}\text { Zbudowanie oferty usług doradczych - raporty HB-HTA, recenzje raportów, określenie } \\
\text { warunków wdrożenia przez szpitale, opiniowanie decyzji i regulacji, doradztwo w zakre- } \\
\text { sie strategii wspomagania rozwoju HB-HTA }\end{array}$ \\
\hline $\begin{array}{l}\text { Rozwój, upowszechnianie wiedzy i dobrych praktyk } \\
\text { oraz budowa bazy wiedzy w zakresie HB-HTA }\end{array}$ & $\begin{array}{l}\text { Rozwój badań naukowych, publikacje, budowanie rejestrów raportów i wdrożeń, prowa- } \\
\text { dzenie analiz przeglądowych i analiz rynkowych dotyczących rynku nowych technologii } \\
\text { medycznych. } \\
\text { Stworzenie i prowadzenie bazy wiedzy o wynikach analiz/raportów/ekspertyz } \\
\text { w zakresie HB-HTA oraz wdrożeń HB-HTA (aspekty organizacyjne, ekonomiczne, } \\
\text { społeczno-etyczne) }\end{array}$ \\
\hline $\begin{array}{l}\text { Rozwój kompetencji kadry zarządzającej, klinicy- } \\
\text { stów i środowiska naukowego w zakresie HB-HTA } \\
\text { oraz stworzenie sieci współpracy w tym zakresie }\end{array}$ & $\begin{array}{l}\text { Rozwijanie badań typu action research, organizowanie warsztatów, treningów, szkoleń } \\
\text { i konferencji, rozwój profesjonalnej kadry własnej i współpracującej, działalność } \\
\text { networkingowa }\end{array}$ \\
\hline
\end{tabular}


szpitalnych, zwiększyć możliwości uzyskiwania przewagi rynkowej oraz dostarczyć argumentów dla poszerzania koszyka świadczeń gwarantowanych o nowe technologie finansowane po racjonalnie oszacowanych stawkach.

Poważne konsekwencje miałoby wdrażanie HB-HTA w modelu opierającym się na NOZ także dla wszystkich przedstawicieli grupy określonej jako profesjonaliści sektora opieki zdrowotnej (tabela 1). Dla tej grupy interesariuszy NOZ staje się nowym, sprzyjającym im podmiotem, niezależnym politycznie i biurokratycznie, wspierającym w racjonalny sposób uzasadnione merytorycznie inicjatywy klinicystów oraz przedsięwzięcia wdrożeniowe i analityczne. Dla wszystkich tych interesariuszy duże znaczenie ma niezależny charakter opinii wydawanych przez NOZ.

Duże konsekwencje wdrażania HB-HTA w Polsce przy udziale NOZ przewidywane są dla wszystkich interesariuszy $\mathrm{z}$ grupy podmiotów silnie powiązanych z naukowymi, metodologicznymi i dydaktycznymi aspektami HB-HTA (tabela 1). Pojawiłaby się nowa sfera badań naukowych, dydaktyki i usług doradczych, a także nowe możliwości rozwoju kadr, współpracy krajowej i międzynarodowej, a więc ogólnie - nowe możliwości wszechstronnego rozwoju działalności tej grupy.

NOZ jako ośrodek promujący rozwój HB-HTA oraz racjonalne i efektywne kosztowo wydatkowanie publicznych pieniędzy wydatkowanych na opiekę zdrowotną stałby się partnerem dla NFZ, wspierającym tę instytucję w realizacji jej misji i ustawowo określonych zadań. Wyniki analiz HB-HTA dostarczałyby nowych, racjonalnych argumentów w negocjacjach dotyczących kontraktowania świadczeń opieki zdrowotnej, wpływając na ich wyniki oraz wartość zawieranych umów. Należy mieć nadzieję, że zostałyby wypracowane zasady partnerskiej współpracy w imię realizacji zbieżnych celów oraz dla skutecznego wdrażania polityki państwa w obszarze wdrażania HB-HTA w Polsce.

\section{Zarys procesu HB-HTA i realizacji zleceń na ustugi doradcze}

Zakłada się, że grupa interesariuszy, którzy mogą zgłosić potrzebę przeprowadzenia analizy HB-HTA, a w ten sposób zainicjować proces HB-HTA, jest stosunkowo liczna. Są wśród nich przede wszystkim szpitale, lecz także organizacje określone skrótowo i ogólnie jako „urzędy” (np. MZ, urząd wojewódzki), organizacje pozarządowe (np. stowarzyszenia pacjenckie), a także przemysł medyczny (w tym farmaceutyczny). Organizacje te składają wniosek o przeprowadzenie analizy HB-HTA do NOZ, gdzie jest on poddawany analizie merytorycznej (feasibility study) z udziałem konsylium eksperckiego. Celem tej analizy jest oszacowanie wykonalności zgłaszanej analizy HB-HTA (wypełnienia potrzeby zgłaszanej przez interesariusza), ocenienie potrzeby ewentualnych modyfikacji wniosku, przygotowanie odpowiedzi dla wnioskodawcy. Zakłada się, że dla przygotowania analizy merytorycznej możliwe będzie korzystanie nie tylko z własnych profesjonalnych zasobów kadrowych NOZ, lecz również elastyczne sięganie po wsparcie ze strony ekspertów zewnętrznych, współpracujących z NOZ i określanych w diagramach jako „baza ekspertów-współpracowników”.

$\mathrm{Na}$ podstawie przeprowadzonej analizy merytorycznej przygotowywana jest oferta dla zleceniodawcy. Planuje się, że na tym etapie NOZ będzie oferować także możliwość poszukiwania źródeł finansowania dla realizacji planowanego zlecenia, np. poprzez dotarcie do ewentualnych grantodawców (szczególnie istotne np. dla organizacji pozarządowych, w tym stowarzyszeń pacjenckich). Oferta przedstawiana jest potencjalnemu zleceniodawcy i ewentualnie dalej z nim negocjowana. W przypadku odrzucenia oferty proces decyzyjny kończy się. Gdy wynegocjowana oferta zostaje przyjęta, podpisywana jest przez obie strony umowa cywilnoprawna na wykonanie analizy HB-HTA lub recenzji raportu HB-HTA (przez recenzję rozumiana jest merytoryczna ocena uprzednio przeprowadzonej analizy HB-HTA, przedstawionej w postaci raportu HB-HTA). Zakłada się, że już na tym etapie NOZ będzie proponował zleceniodawcy klauzulę umowną o wykonaniu analizy prospektywnej, w przypadku ostatecznego wdrożenia technologii.

Po podpisaniu przez NOZ oraz zleceniodawcę umowy cywilnoprawnej w jej ostatecznej postaci umowa ta jest realizowana i przygotowywany jest raport HB-HTA lub recenzja raportu HB-HTA (ogólnie określane w tym opracowaniu jako analizy HB-HTA). Zakłada się, że na tym etapie NOZ będzie współpracował z różnymi organizacjami sektora ochrony zdrowia, takimi jak: NFZ, AOTMiT, wieloma instytucjami badawczymi i środowiskiem ekspertów, a także z MZ. Współpraca ta będzie konieczna dla realizacji misji i podstawowych celów funkcjonowania NOZ. W ten sposób możliwe będzie pozyskiwanie danych niezbędnych dla realizacji zlecenia i przeprowadzenia analizy HB-HTA, uzupełniających dane dostarczane przez zleceniodawcę lub powszechnie dostępne w domenie publicznej, czy też dostępne za pośrednictwem specjalistycznych baz danych (baz informacyjnych). Współpraca z wieloma organizacjami sektora ochrony zdrowia będzie też podstawowym elementem „sieciowania HB-HTA”, budowania sieci współpracy wielu interesariuszy zaangażowanych w rozwój HB-HTA, uczących się $\mathrm{W}$ miarę przyrastania liczby wykonanych analiz HB-HTA. Powinno to wspomagać proces budowania świadomości w zakresie HB-HTA - zarówno w środowisku profesjonalistów ochrony zdrowia, jak też w szerokiej świadomości społecznej.

Budowaniu świadomości społecznej w zakresie HB-HTA będzie służyć także inna sfera działalności NOZ, jaką jest stworzenie i ustawiczne rozbudowywanie zasobu wiedzy z zakresu HB-HTA, określonego jako „baza wiedzy, repozytorium wiedzy”. Będzie z nim ściśle współgrać sfera działalności NOZ określona jako „edukacja w zakresie HB-HTA i promocja dobrych praktyk". Do zadań i elementów misji NOZ należeć będzie nie tylko wykonawstwo kolejnych analiz HB-HTA, lecz również pełnienie funkcji edukacyjnych i propagowanie HB-HTA jako interdyscyplinarnej działalności poprawiającej jakość opieki zdrowotnej w Polsce. 
Kształt raportu HB-HTA, a w szczególności jego charakter i układ treści, zależeć będą od konkretnego zleceniodawcy i jego potrzeb odnośnie do rodzaju wykonywanej analizy. Zakłada się, że co do zasady będzie on kończył się rekomendacją dla zleceniodawcy na temat wdrożenia danej technologii szpitalnej, zaś warianty tej rekomendacji mogą być następujące - pozytywna, negatywna lub warunkowo pozytywna (tzn. pozytywna, lecz pod warunkiem spełnienia dodatkowych warunków). Przewidywane jest zaproponowanie zleceniodawcy dalszej współpracy, związanej z udzieleniem pomocy we wdrożeniu technologii i/lub edukacją z tym związaną, szkoleniem zleceniodawcy, a także np. poszukiwaniem finansowania dla wdrożenia technologii.

\section{Przebieg procesu HB-HTA, relacja podmiotów w kontelśsie przeptywu danych, produktów, us'ug w ramach modelu}

Działania NOZ można podzielić na główne, wynikające z misji tej organizacji i decydujące o jej trwaniu, oraz pomocnicze, służące ich organizacji, optymalizacji, innowacyjności itp.

Do procesów głównych należą:

1. Prowadzenie analiz HB-HTA na zlecenie jednostek zamawiających, $\mathrm{z}$ uwzględnieniem specyficznych potrzeb tych jednostek, połączone $\mathrm{z}$ realizacją opcjonalnych usług powdrożeniowych i wymagające wsparcia przez wiele procesów pomocniczych.

2. Budowanie rozpoznawalności marki i utrzymanie pozycji rynkowej NOZ - działania marketingowe oraz z zakresu public relations, oparte na bliskiej współpracy z ekspertami, bogatej bazie wiedzy oraz szerokiej ofercie analitycznej i doradczej. Działania te zapewniają „przetrwanie” NOZ na rynku oraz w systemie ochrony zdrowia, służąc budowaniu stabilnego finansowania, dzięki któremu organizacja może realizować swoją misję. NOZ może utrzymywać się z różnych źródeł finansowania, przynosić zysk lub być jednostką typu non-profit - ważne, aby dzięki swej marce pozyskiwała środki na stabilne funkcjonowanie.

3. Budowanie bazy wiedzy - systematyczne gromadzenie, w trakcie wykonywanych analiz i przeglądów, literatury, informacji, materiałów i innowacji medycznych. Obejmuje to również budowanie i publikowanie katalogu opracowań specjalistycznych z obszaru HB-HTA. Kształt bazy wiedzy zależeć będzie od aktywności i różnorodności ekspertów zaangażowanych w prace NOZ.

4. Działalność edukacyjna dla kadry szpitali - informowanie o tym, czym jest HB-HTA, wyjaśnianie, do czego służą analizy HB-HTA, pokazywanie pozytywnych efektów wdrożeń dokonanych z wykorzystaniem HB-HTA.

Opisane powyżej procesy stanowią czworokąt wspierających się działań. Wysoka jakość procesu nr 1 będzie wspierać skuteczność procesu nr 2. Proces nr 3 wpływa na jakość analiz, zaś działalność edukacyjna (proces nr 4) wpływa na budowanie marki i wzrost liczby prowadzonych analiz.
Procesy pomocnicze są to działania, które służą wykonaniu i obsłudze procesów głównych. Wyróżniono osiem procesów pomocniczych:

1. Budowanie bazy ekspertów poprzez stałą rekrutację i aktualizację. Ekspertami w bazie NOZ mogą być m.in. lekarze, fizycy medyczni, biolodzy, epidemiolodzy, farmaceuci, informatycy, ekonomiści, statystycy, psycholodzy, socjolodzy, prawnicy itp. Działania prowadzone w ramach tego procesu to:

a) utrzymanie bezpośrednich kontaktów z osobami opiniotwórczymi w środowisku ochrony zdrowia, gromadzenie danych kontaktowych, informacji o osiągnięciach naukowych, menadżerskich, informacji o dostępności ekspertów;

b) współpraca z uczelniami medycznymi i innymi rodzajami uczelni, np. politechnikami. Prowadzenie bazy kontaktów osobowych oraz wydarzeń edukacyjnych i naukowych mających związek z szeroko rozumianymi technologiami medycznymi;

c) udział w publikacjach i konferencjach, prezentacja zagadnień interesujących partnerów.

2. Budowa i utrzymanie narzędzi informatycznych:

a) służących gromadzeniu informacji o ekspertach oraz prowadzeniu komunikacji z nimi;

b) służących gromadzeniu i udostępnianiu informacji z bazy wiedzy, zarówno dla potrzeb wewnętrznych NOZ, jak też dla użytkowników zewnętrznych;

c) służących szkoleniom, np. e-learning;

d) wewnętrznej obsługi procesu tworzenia analiz, w tym narzędzi zarządzania projektem, narzędzi analitycznych, obliczeniowych, statystycznych, narzędzi agregowania i prezentacji danych;

e) utrzymanie lub wynajem infrastruktury technicznej, rozwój narzędzi programistycznych, administracja infrastruktury IT.

3. Współpraca z urzędami i instytucjami centralnymi, w tym obejmująca:

a) utrzymanie stałego kontaktu z przedstawicielami instytucji decyzyjnych $\mathrm{w}$ ochronie zdrowia na poziomie centralnym i regionalnym oraz przedstawianie wniosków z analiz;

b) opiniowanie projektów przedstawianych przez instytucje centralne oraz regionalne, branie udziału w konsultacjach społecznych, przedstawianie opinii o wydawanych aktach prawnych;

c) przygotowywanie raportów własnych o zjawiskach zachodzących na rynku ochrony zdrowia na podstawie bazy wiedzy. Może to być np. tworzenie i publikacja cyklicznego raportu (np. raz w roku) o rozwoju i wdrożeniach technologii medycznych na polskim rynku ochrony zdrowia oraz przeglądu eksperckiego innowacji na rynku światowym.

4. Szkolenia dla podmiotów leczniczych z zakresu zarządzania projektami wdrożeniowymi oraz ekonomizacji procesu leczenia, służące budowaniu świadomości na temat korzyści płynących $\mathrm{z}$ procesu HB-HTA.

5. Poszukiwanie finansowania dla podmiotów zamawiających analizy. Szpitale mogą mieć problem z podjęciem decyzji o wydatkowaniu środków 
na usługi konsultingowe (taki bowiem charakter mają usługi NOZ), zaś wsparcie w formie zewnętrznego finansowania może ułatwić decyzje o podjęciu przez szpital ,wysiłku” analizy HTA.

6. Wspólne z Zamawiającym wdrażanie rozwiązań wynikających z przeprowadzonej analizy. Ułatwi to uzyskanie wymiernych efektów w postaci przeprowadzonego $\mathrm{z}$ sukcesem wdrożenia i prowadzenia dalszych analiz prospektywnych.

7. Obsługa prawna, tj. tworzenie i przestrzeganie zasady ochrony i udostępniania gromadzonych danych, oraz obsługa prawna umów podpisywanych ze zleceniodawcami, ekspertami i podwykonawcami.

8. Monitorowanie rynku, formułowanie odpowiedzi na zapytania ofertowe, w tym przetargowe, systematyczne odpowiadanie na pojawiające się zapytania oraz stałe monitorowanie rynku.

\section{Struktura projektowa NOZ}

Świadcząc usługi badawcze i doradcze dla szpitali i innych podmiotów zainteresowanych oceną szpitalnych technologii medycznych w szerokim zakresie i rozumieniu znaczenia terminu HB-HTA, NOZ ma być nowoczesnym, profesjonalnym ośrodkiem doradczo-analityczno-badawczym, opierającym się na pracy interdyscyplinarnych zespołów projektowych. W strukturze NOZ miałby być utworzony zespół określony mianem Zespołu Projektowego, którego zakres działania, konstrukcja i skład kadrowy zależeć będą od potrzeb i zakresu zadań wymaganych przez podmiot zamawiający usługę analityczną (Zamawiającego) i wyrażonych w zamówieniu (wniosku) skierowanym do NOZ, a następnie indywidualnie negocjowanym pomiędzy $\mathrm{NOZ}$ (Zleceniobiorcą) a Zamawiającym (w rezultacie pomyślnego przebiegu negocjacji stającego się następnie Zleceniodawcą). Określenie zakresu prac i innych warunków umownych (czas wykonania, potrzebne informacje itd.) oraz wycena usługi świadczonej przez NOZ będą miały charakter indywidualny, dopasowany do potrzeb Zleceniodawcy.

Przewiduje się, że w projektowej strukturze organizacyjnej NOZ istotne znaczenie posiadać będą także stały Zespół Główny oraz Baza Ekspertów Zewnętrznych. Niezależnie od ostatecznie przyjętej struktury formalnej funkcjonowanie NOZ oparte będzie na stałej współpracy w gronie kilku ekspertów z dużym doświadczeniem z obszaru wiedzy i praktyki ekonomicznej, medycznej i prawnej, $\mathrm{z}$ uwzględnieniem zagadnień HTA, posiadających wysokie kompetencje badawcze i projektowe. Zespół ten, określony jako Zespół Główny, współtworzy i reprezentuje na zewnątrz NOZ, posiadając umiejętności, wiedzę i zakres odpowiedzialności pozwalające na kreowanie marki i utrzymywanie wysokiej jakości świadczonych usług, unifikację metodyki pracy i gwarantowanie ciągłego doskonalenia procesów. Oprócz wysoko ocenianej wiedzy i specjalistycznych umiejętności zawodowych Zespół Główny ma posiadać ogólnie definiowane kompetencje, takie jak: umiejętność budowania relacji i pracy w zespole, umiejętności sprzedażowe i negocjacyjne, zaangażowanie i wysoka jakość wykonywanej pracy, umiejętności w zakresie zarządzania (czasem, pracą, projektami, pracownikami), zawodowe, wynikające z wiedzy i umiejętności specjalistycznych w obszarze HTA. Poza stałym Zespołem Głównym, stanowiącym kompetencyjny trzon NOZ, niezbędne będzie zaangażowanie do współpracy personelu do obsługi administracyjnej, księgowej i innej (np. informatycznej, z zakresu public relations), związanych z realizacją procesów natury niestrategicznej.

Ideą struktury projektowej NOZ jest stworzenie zespołów zadaniowych powoływanych do realizacji ściśle określonych zadań, związanych z konkretnymi zamówieniami od Zamawiających. Zlecane zadania będą miały kompleksowy i innowacyjny charakter oraz ściśle określoną treść, zakres przedmiotowy, koszt i termin realizacji. Przewiduje się, że dla potrzeb realizacji konkretnego projektu powołany będzie jego kierownik, posiadający odpowiednie uprawnienia decyzyjne i odpowiedzialny za końcowy wynik projektu. Zespół wykonawczy struktury projektowej powinien się składać z takiej liczby specjalistów o różnorodnych umiejętnościach i kwalifikacjach, która jest odpowiednia do zakresu i charakteru zadań oraz dopasowana do rodzaju i charakteru projektu.

Obok istnienia Zespołu Głównego zakłada się funkcjonowanie grupy ekspertów zewnętrznych (m.in. profesjonalistów $\mathrm{z}$ wielu specjalności medycznych oraz posiadających doświadczenie zarządcze, ekonomiczne, finansowe i biznesowe), których nabór miałby być organizowany w trybie ciągłym. Pozwalałoby to na zbudowanie bazy ekspertów i kandydatów na ekspertów, mających w przyszłości współpracować z NOZ (Baza Ekspertów Zewnętrznych). Profil zawodowy tych osób, $\mathrm{w}$ tym np. reprezentowaną przez nich dziedzinę medyczną, można by łączyć w odpowiednim momencie z zamówieniem od konkretnego interesariusza i specyfiką ocenianej szpitalnej technologii medycznej.

Innego rodzaju istotną kwestią w działalności NOZ byłby nabór na ekspertów zewnętrznych, oceniających pod względem merytorycznym wnioski o współpracę w konkretnym zamówieniu. Osoby zainteresowane współpracą w wymaganym zakresie przesyłałyby uzupełniony wniosek o wpis do bazy kandydatów/ekspertów, przedstawiając w nim swój profil zawodowy, zaś $\mathrm{w}$ razie rozpoczęcia współpracy podpisywałyby ramową umowę o współpracy (umowę o dzieło). Przewiduje się, że kategoryzacja ekspertów uwzględniałaby następujące profile eksperckie: ekonomiczny, administracyjny i zarządczy, prawny, farmaceutyczny, statystyczny oraz profil medyczny.

W sytuacji gdy Zamawiającym będzie szpital posiadający w swojej strukturze kadrę $\mathrm{z}$ kompetencjami niezbędnymi do realizacji zadania lub jeśli to właśnie szpital (np. poprzez zatrudnionych w nim klinicystów) będzie inicjatorem danej innowacji, to w zależności od treści zamówienia na usługę HB-HTA, stosownie do potrzeb, uzupełniane będą komponenty niezbędne do realizacji zlecenia. Założenia i przewidywania dotyczące współpracy NOZ z Zamawiającym będącym szpitalem, który posiada w swojej strukturze stosowny 
dział zajmujący się analityką szeroko rozumianą jako HTA (dział nowych technologii medycznych), są pomyślne dla polityki rozwoju HB-HTA w Polsce. Szpital tego rodzaju występowałby do NOZ z propozycją zamówienia usługi związanej z realizacją własnych zadań statutowych. Pole do współpracy w takim przypadku byłoby szerokie - od nawiązania partnerskich relacji po szeroko zakrojone aspekty badawcze i publikacyjne.

W strukturze szpitala (klinicznego - z dużym prawdopodobieństwem) dział HB-HTA mógłby być ulokowany w pionie medycznym. Otrzymywałby on silne wsparcie analityczne ze strony działu kontrolingowego, a także dostęp do danych umożliwiających prowadzenie analiz klinicznych, bezpieczeństwa, ekonomicznych oraz zasadności wdrożenia nowej technologii. Szpitalny dział HB-HTA byłby zasilony pracownikami posiadającymi kompetencje w zakresie przeszukiwania baz danych, wykonywania przeglądów systematycznych i właściwej ekstrakcji danych oraz cechującymi się zdolnościami analitycznymi. Zalecane jest przyjęcie do stosowania odpowiedniej procedury lub zarządzenia, które na zasadzie listy kontrolnej i formularza zdefiniowałyby sposób postępowania z danym zagadnieniem analitycznym i innowacją.

\section{Rola i zadania statutowe NOZ w systemie HB-HTA}

Przyjęto założenie, że NOZ będzie specjalizować się w problematyce HTA i HB-HTA jako organizacja badawcza i doradcza, świadcząca w ramach swojej działalności podstawowej usługi w zakresie doradztwa (konsultingu) dla szpitali i wszystkich innych podmiotów zainteresowanych wszechstronną oceną technologii medycznych, w tym odpłatnie na ich zlecenie. Utworzenie i działanie NOZ nie będzie ograniczać zakresu dotychczasowej działalności instytucji regulujących, w szczególności nie zmieni uprawnień tych instytucji do standaryzacji wymogów stawianych raportom HB-HTA, akceptacji nowych technologii i decyzji o ich finansowaniu ze środków publicznych. Dla NOZ przewidziano więc rolę uzupełniającą w systemie ochrony zdrowia, nie zaś konkurencyjną względem już istniejących podmiotów.

Misją NOZ ma być świadczenie usług różnym interesariuszom, przede wszystkim szpitalom, ale również władzom publicznym, organizacjom społecznym (w tym stowarzyszeniom pacjentów), przedsiębiorcom (producentom i dystrybutorom wyrobów medycznych) oraz płatnikom świadczeń zdrowotnych (publicznemu i niepublicznym). W zakresie podstawowej działalności NOZ znajdzie się niezależne prowadzenie prac badawczo-rozwojowych i wdrożeniowych oraz transfer wiedzy w zakresie HTA i HB-HTA poprzez dokonywanie ocen technologii medycznych pod względem:

- efektów klinicznych (skuteczność, ryzyko, bezpieczeństwo, medyczne wskazania kliniczne do zastosowania szpitalnych technologii medycznych);

- skutków finansowych (koszty szpitala, wpływ na budżet szpitala, wpływ na budżet innych podmiotów, koszty zewnętrzne, ponoszone m.in. przez pacjentów i ich rodziny);
- efektywności ekonomicznej, w tym finansowej, z punktu widzenia szpitala i innych podmiotów w systemie ochrony zdrowia, a także relacji koszt-efekt i koszt-użyteczność;

- uwarunkowań epidemiologicznych (częstość występowania potrzeb zdrowotnych, do których odnoszą się oceniane technologie szpitalne, wpływ zastosowania technologii na populacyjne wskaźniki zdrowia itp.);

- korzyści zdrowotnych dla pacjenta, ocenianych obiektywnie i subiektywnie na podstawie szeregu wskaźników (m.in. liczby zyskanych lat życia skorygowanych o jakość [Quality-Adjusted Life Years, QALY], ograniczenia zagrożenia chorobą, ograniczenia wystąpienia/ rozwoju chorób współistniejących), a także innych korzyści (zwiększony komfort, zmniejszenie obciążenia czasowego i finansowego itp.);

- wymogów etycznych.

Do podstawowej działalności NOZ należałoby także udzielanie dostępu do sukcesywnie rozwijanej wiedzy z zakresu HTA i HB-HTA (bazy danych, repozytorium wiedzy) i działalność edukacyjna (wykłady, konwersatoria, warsztaty) ukierunkowana na upowszechnianie wiedzy i trening umiejętności oraz działalność publikacyjną. Realizacja usług odbywać się będzie w formie analiz, ekspertyz, ocen, opinii, recenzji, potrzebnych w procesie przygotowywania raportów HB-HTA, i innych opracowań służących wypromowaniu i wdrożeniu w szpitalach nowych technologii medycznych, a także szkoleń i pomocy we wdrażaniu szpitalnych technologii medycznych (coaching, doradztwo w procesie decyzyjnym, pomoc w opracowaniu rozwiązań organizacyjnych).

Elastyczność może być dużym atutem, umożliwiającym szybki i szeroki rozwój systemu HB-HTA, niezależnie od wyjściowego poziomu przygotowania polskich szpitali, w różnym stopniu zaawansowanych w zakresie możliwości samodzielnego, całościowego przygotowania raportów HB-HTA oraz mających w różnym stopniu rozwinięte struktury i potencjał kadrowy. Raport opracowany przez szpital może wymagać uzupełnień lub korekty, zarówno z punktu widzenia klinicznego, jak też ekonomicznego i epidemiologicznego, zaś jego szybkie i profesjonalne uzupełnienie, ocena, modyfikacja i udostępnienie innych usług będą stanowić wartościową ofertę ze strony NOZ.

Ogólna baza wiedzy będzie udostępniana nieodpłatnie (z wyłączeniem dostępu do danych indywidualnych zleceniodawców), podobnie jak inne, ogólnie dostępne formy rozpowszechniania wiedzy (wykłady, prelekcje). Publikacje NOZ mogą być sprzedawane lub dofinansowywane ze środków publicznych. Zakłada się, że istotnym źródłem finansowania NOZ będą granty badawcze i wdrożeniowe, współfinansowane ze środków Unii Europejskiej (UE) oraz środków krajowych (np. Narodowe Centrum Badań i Rozwoju), i inne formy pomocy publicznej. Finansowanie NOZ będzie opierać się na zróżnicowanych źródłach, zależnych od wybranej formy prawnej działania, determinującej obligatoryjne i potencjalne źródła finansowania. 


\section{Możliwe formy prawne działania NOZ}

NOZ ma być organizacją niezależną, zaś ten atrybut jest stopniowalny i związany z siłą i zakresem administracyjnej kontroli zewnętrznej nad organizacją. Generalnie rzecz biorąc, organizacja niezależna sama wyznacza swoją strategię, opracowuje plany operacyjne (w tym finansowe) i podejmuje decyzje bez konieczności zatwierdzania przez jednostkę/agendę administracyjną, samodzielnie finansując swoją działalność i ponosząc odpowiedzialność za wyniki finansowe. Z kategorii organizacji niezależnych należy wykluczyć wszelkie instytucje i agendy rządowe oraz samorządowe, a także organizacje, dla których podmiotem tworzącym jest Skarb Państwa albo organy jednostek samorządu terytorialnego.

Atrybut niezależności odnosi się do organizacji pozarządowych i gospodarczych. Podmioty sektora pozarządowego (non-governmental organizations, NGO), w tym non-profit (nieprowadzące działalności gospodarczej) oraz not-for-profit (łączące działalność o celach społecznych z działalnością gospodarczą), to zwykle fundacje i stowarzyszenia (więcej na ten temat m.in. w [7]). $\mathrm{Z}$ niezależnym biznesem (przedsiębiorczością) wiąże się przede wszystkim działalność różnego rodzaju spółek prawa handlowego, powołanych przez podmioty prywatne. Do niezależnych organizacji gospodarczych zalicza się również m.in. spółdzielnie i spółki pracownicze. Warto jednak zauważyć, że zarówno organizacje gospodarcze, jak i pozarządowe podlegają regulacjom, w różnym stopniu ograniczającym ich pełną niezależność.

Wyższe uczelnie (publiczne i niepubliczne), traktowane jak przedsiębiorca $\mathrm{w}$ zakresie realizacji odpłatnych usług, mogłyby z łatwością podjąć działalność edukacyjną i badawczą w zakresie HB-HTA, a także wykonywać prace doradczo-wdrożeniowe w tym zakresie, poprzez stworzenie odrębnych struktur wewnętrznych (więcej na ten temat m.in. w [8]). W zależności od poziomu posiadanych kompetencji wymagałoby to niewielkich lub większych nakładów - oparcia się na już posiadanych kompetencjach zatrudnionych pracowników naukowo-dydaktycznych oraz ich autorytecie profesjonalnym. Skupienie specjalistów z różnych dziedzin, potrzebnych w ramach doradztwa z zakresu HTA i HB-HTA (klinicystów, specjalistów z zakresu nowoczesnych technologii medycznych, ekonomistów zdrowotnych, epidemiologów itp.), byłoby dodatkowym atutem. Uczelnie miałyby szanse na uzyskiwanie dodatkowych przychodów, z możliwością przeznaczania ich na rozwijanie kompetencji i autorytetu w obszarze HB-HTA.

Scenariusze tworzenia ,niezależnej organizacji / jednostki zewnętrznej" są więc otwarte i mogą dotyczyć szeregu form prawnych i rozwiązań organizacyjnych, w tym sieci współpracujących organizacji. Wybór pociąga za sobą implikacje nie tylko dla samego procesu utworzenia NOZ (czas trwania i stopień skomplikowania procesu formalizacji, wymogi odnośnie do wysokości zaangażowanego kapitału, zagwarantowanie środków finansowych, zwłaszcza na początkową fazę rozwoju organizacji), ale także dla czynników sukcesu tej organizacji (m.in. ciągłości, szans pozyskania i rozwoju przychodów na sfinansowanie działalności statutowej, stopnia skomplikowania systemu zarządzania, zaufania potencjalnych zleceniodawców). Niezależnie od wybranej formy podstawowym warunkiem efektywnego działania NOZ jest oparcie się na autorytecie profesjonalnym, a jednocześnie na przedsiębiorczości.

Warto podkreślić, że działając w każdej z możliwych form prawnych, NOZ będzie mogła skutecznie ubiegać się o status organizacji badawczej, spełniając wymogi stawiane takiej organizacji. Status organizacji badawczej dałby NOZ możliwość korzystania $\mathrm{z}$ różnorodnych form pomocy publicznej na mocy rozporządzenia Komisji Europejskiej nr 651/2014 z dnia 17 czerwca 2014 r. uznającego niektóre rodzaje pomocy za zgodne $\mathrm{z}$ rynkiem wewnętrznym w zastosowaniu art. 107 i 108 Traktatu $^{2}$. Niezależnie od posiadania tego statusu każda z form działania NOZ umożliwia aplikowanie o finansowanie z projektów badawczych, rozwojowych, wdrożeniowych lub szkoleniowych ze środków UE i krajowych - samodzielnie lub jako partner w ramach konsorcjów, a także korzystanie $\mathrm{z}$ innych dostępnych form pomocy publicznej.

\section{Bariery i możliwości rozwoju NOZ}

Najważniejsze możliwości, ale zarazem bariery, wynikają z immanentnych cech NOZ, takich jak: profesjonalizm i specjalizacja, pozostawanie poza systemem sztywnych regulacji $\mathrm{w}$ ochronie zdrowia, brak formalnych uprawnień do standaryzacji procesu HB-HTA oraz rynkowy charakter oferowanych usług. Powołanie i funkcjonowanie NOZ stworzyłoby możliwość znaczącego uzupełnienia i wzbogacenia sieci HB-HTA. Głównymi interesariuszami zewnętrznymi powinni być dla NOZ przede wszystkim jej potencjalni zleceniodawcy usług doradczych, a wśród nich: szpitale wykonujące raporty HB-HTA i wdrażające nowe technologie, które z braku dostatecznych kompetencji mogą potrzebować uzupełnienia oraz pomocy profesjonalnej; przedsiębiorcy produkujący i sprzedający innowacyjne produkty oraz zmieniający szpitalne technologie medyczne; organizacje pacjenckie oraz podmioty publiczne (urzędy), które mogą potrzebować profesjonalnej niezależnej opinii lub recenzji odnośnie do różnych aspektów oceny szpitalnych technologii medycznych.

Ważnym uwarunkowaniem skorzystania z usług NOZ może być kondycja finansowa szpitali. W złej sytuacji finansowej motywacją organu tworzącego może być konieczność dokonania restrukturyzacji lub wycofania/ograniczenia starych, niskoefektywnych technologii i wprowadzenia nowych.

Niewątpliwie barierą w skorzystaniu z pomocy NOZ przez szpitale będzie konieczność poniesienia kosztu usługi. Zakłada się jednak, że szereg usług - świadczonych w ramach pozyskanych grantów krajowych i zagranicznych - będzie mogło być dostarczone bezpłatnie lub na warunkach współpłacenia pokrywającego w niewielkim stopniu koszt usługi.

Barierą mogą być też wątpliwości szpitali oraz innych zleceniodawców co do przydatności usług doradczych NOZ w sytuacji, gdy inne podmioty (instytucje 
standaryzujące) będą miały uprawnienia do oceniania raportu HB-HTA oraz uprawnienia decyzyjne w zakresie finansowania nowych technologii medycznych i usług wykonywanych przy ich zastosowaniu. Dużą rolę będzie odgrywał poziom zaufania do profesjonalizmu NOZ i obiektywizmu dokonywanych analiz. Instytucje regulujące w obszarze HB-HTA mogą postrzegać NOZ jako organizację „konkurencyjną” - w tym sensie, że NOZ będzie wykonywać usługi w zakresie, w którym instytucje standaryzujące mają uprawnienia decyzyjne. Jednak - z drugiej strony - instytucje te mogą postrzegać usługi NOZ jako pomocne w ocenie $\mathrm{i}$ w procesie analizowania wariantów decyzji, które muszą podejmować w procesie administracyjnym. Usługi NOZ mogą w dużej mierze służyć nadzorowi właścicielskiemu nad szpitalami, których organem tworzącym jest MZ, jak też wspomaganiu procesów decyzyjnych w zakresie HB-HTA w AOTMiT oraz NFZ.

Opór instytucji regulujących może powodować obawa o ewentualne rozbieżności pomiędzy ich ocenami a wynikami analiz NOZ. Zakładając jednak, że HB-HTA ma opierać się na dowodach obiektywnych empirycznych, w przypadku rozbieżności konfrontacja argumentów służyłaby przejrzystości i racjonalności całego procesu.

NOZ powinna zapewnić sobie współpracę ze środowiskiem krajowych (jak też zagranicznych) ekspertów w zakresie HB-HTA, z uczelniami i firmami doradczymi oraz z zagranicznymi ośrodkami zajmującymi się analizami w obszarze HB-HTA. Im wyższy poziom ekspercki zapewniałaby NOZ, tym bardziej rosłaby jej rola w sieci, oparta na autorytecie profesjonalnym. Niewątpliwie inne ośrodki doradcze i uczelnie starałyby się konkurować z NOZ, stosując strategie konkurowania globalnego i niszowego. Z niektórymi z nich NOZ musiałaby skonfrontować się na rynku usług doradczych, konkurując elastycznością oferty, relatywnie niższą ceną i wysokim profesjonalizmem. Być może NOZ musiałaby ograniczyć pewne rodzaje usług, w których realizacji okazałaby się słabsza od konkurencji, a wyspecjalizować tylko w niektórych.

\section{Potenciał NOZ w dziedzinie HB-HTA w Polsce}

Spośród wszystkich omawianych wariantów wdrożenia systemu HB-HTA w Polsce model oparty na NOZ jest jedynym, który zakłada utworzenie całkiem nowej, nieistniejącej jeszcze organizacji, specjalizującej się w przeprowadzaniu kompleksowej oceny technologii medycznych $\mathrm{z}$ perspektywy szpitali. Z tego względu analiza potencjału NOZ ma charakter prospektywny i koncentruje się przede wszystkim na mocnych stronach tego modelu oraz warunkach utworzenia od podstaw nowoczesnej, efektywnie działającej organizacji, oferującej usługi dostosowane do potrzeb szpitali.

$\mathrm{W}$ porównaniu $\mathrm{z}$ alternatywnymi wariantami wdrożenia HB-HTA NOZ wyróżnia się znaczną autonomią i elastycznością, dzięki czemu jednostkę tę cechuje wysoka zdolność dostosowania się do potrzeb, wymagań i warunków zleceniodawców (głównie szpitali). Uproszczona struktura organizacyjna, zgodna z koncepcją lean management, przekłada się na większą niż w przypadku pozostałych modeli zadaniowość, proaktywność, orientację na cel i efektywność działania. Działalność NOZ będzie wymagała nawiązania i utrzymywania współpracy $\mathrm{z}$ wieloma specjalistami $\mathrm{z}$ różnych dziedzin, a zatrudnienie doświadczonych ekspertów będzie się odbywało w znacznej mierze w formie pozaetatowej, na zasadach rynkowych.

Warunkiem prowadzenia efektywnej działalności NOZ jest nawiązanie współpracy z ekspertami z różnych dziedzin, w tym m.in.: medycyny, epidemiologii, demografii, ekonomii, zarządzania, oceny technologii medycznych i technologii informacyjnych. Dobór odpowiednich specjalistów jest niezbędny dla zapewnienia wysokiej jakości opracowywanych raportów/analiz HTA oraz systematycznego gromadzenia wiedzy z tego obszaru. Stała współpraca z zespołem ekspertów zewnętrznych pozwoli na utrzymanie zgodności raportów z metodyką oceny technologii medycznych oraz rozwój narzędzi wspierających proces HB-HTA.

Sukces NOZ wymaga także zatrudnienia na stałe (w ramach personelu jednostki) specjalistów z zakresu oceny technologii medycznych oraz pozyskiwania i rozliczania dotacji/grantów z zewnętrznych źródeł finansowania. Powyższe jest niezbędne dla efektywnego aplikowania o wsparcie finansowe procesu HB-HTA z dostępnych funduszy i programów.

Model niezależnej organizacji zewnętrznej cechuje się adhokratyczną kulturą i strukturą organizacyjną [9] o wysokiej kreatywności, dynamice i sprawności funkcjonowania, przy minimalnym (niezbędnym do funkcjonowania) stopniu formalizacji. NOZ będzie na bieżąco reagować na zmieniające się otoczenie rynkowe, a także sprawnie dostosowywać się do bieżących wytycznych regulacyjnych. Znaczna elastyczność działania i orientacja na wyniki pozwalają zakładać, że w przypadku NOZ nie występuje zagrożenie nadmierną formalizacją procesu HB-HTA.

Z uwagi na szeroką ofertę oraz dużą liczbę interesariuszy i potencjalnych zleceniodawców NOZ powinna posiadać dostęp do różnego rodzaju danych gromadzonych przez jednostki publiczne na szczeblu centralnym i regionalnym. Z tego względu rozwój działalności NOZ wymaga nawiązania współpracy instytucjonalnej z kluczowymi podmiotami w obszarze ochrony zdrowia, m.in. NFZ, AOTMiT, MZ, ABM, Narodowy Instytut Zdrowia Publicznego - Państwowy Zakład Higieny, Centrum e-Zdrowia (CEZ), wydziałami do spraw zdrowia w urzędach wojewódzkich i marszałkowskich. Współpraca z tymi instytucjami pozwoli na obustronną wymianę wiedzy i doświadczeń z zakresu szpitalnej oceny technologii medycznych, jak również zapewni NOZ dostęp do danych niezbędnych do opracowywania analiz i raportów HB-HTA.

Istotną cechą wyróżniającą NOZ jest jej niezależność i brak ograniczeń w kształtowaniu relacji, zarówno $\mathrm{z}$ instytucjami publicznymi, jak i podmiotami komercyjnymi (np. producentami sprzętu medycznego). NOZ stanowiłaby całkowicie nowy podmiot w polskim systemie ochrony zdrowia, z czasem mając szansę zbudowania 
wizerunku organizacji solidnej, wiarygodnej, działającej na obiektywnych i przejrzystych zasadach. W odróżnieniu od NFZ (płatnika), MZ lub AOTMiT (regulatorów) NOZ nie będzie mieć bezpośredniego wpływu na wprowadzanie określonych regulacji i kontrolę podmiotów leczniczych, dlatego może cieszyć się większym zaufaniem szpitali. Jako wiarygodny i rzetelny partner biznesowy NOZ będzie realizować zlecenia wielu podmiotów leczniczych i uzyska dostęp do różnego rodzaju danych (klinicznych, finansowych i innych).

W modelu NOZ praktycznie nie występuje ryzyko konfliktu interesów pomiędzy ośrodkiem koordynującym (NOZ) a podmiotami sieciowanymi (pojedynczymi szpitalami). Brak istnienia jakichkolwiek zależności pomiędzy NOZ a szpitalami w zakresie kontraktowania świadczeń minimalizuje potencjalny konflikt interesów w zakresie sieciowania i rozwijania HB-HTA na szerszą skalę.

Wszechstronna działalność NOZ, obejmująca zarówno przygotowanie różnego rodzaju opracowań i analiz HB-HTA, jak i szeroką ofertę doradczą i szkoleniową, pozwoli na wypracowanie unikalnego know-how i osiągnięcie przez NOZ mocnej pozycji w obszarze doradztwa. NOZ jest także potencjalnym liderem pod względem upowszechniania wiedzy i działalności edukacyjnej z zakresu HB-HTA i HTA w Polsce. Żadna inna organizacja nie będzie posiadać porównywalnych zasobów kompetencyjnych ani też bazy kontaktów ze szpitalami, ukształtowanych na zasadach dobrowolności, $\mathrm{z}$ dopasowaniem do indywidualnych potrzeb poszczególnych podmiotów.

Model oparty na NOZ jest hipotetyczny, ponieważ według obecnego stanu rzeczy tego rodzaju jednostka nie istnieje. Trudno jest zatem ocenić NOZ pod kątem potencjalnej trwałości i kontynuacji działalności po zakończeniu fazy pilotażowej. Szanse te można jednak uznać za duże, zwłaszcza w sytuacji uzyskania statusu organizacji badawczej i możliwości korzystania ze wsparcia finansowego na rozwój infrastruktury i prowadzenie działalności. Sukces NOZ zależy od szeregu czynników, obejmujących w szczególności: zbudowanie profesjonalnego zespołu, stworzenie bazy ekspertów zewnętrznych, nawiązanie współpracy $\mathrm{z}$ instytucjami publicznymi w ochronie zdrowia, pozyskanie zamówień na ekspertyzy i szkolenia od szpitali i innych zleceniodawców, osiągnięcie mocnej pozycji na rynku, dostępność zewnętrznych źródeł finansowania nowych technologii medycznych, popyt na HTA, regulacje systemowe wspierające proces HB-HTA (np. premiowanie szpitali wdrażających rozwiązania w tym zakresie).

$\mathrm{Z}$ uwagi na przedstawione powyżej mocne strony modelu NOZ warto rozważyć możliwość wdrożenia systemu HB-HTA w Polsce właśnie w tej formie. Należy jednocześnie zauważyć, że nawet w przypadku wyboru innego modelu skala zapotrzebowania na usługi i wsparcie doradcze z zakresu HTA pozwala zakładać, że w sektorze ochrony zdrowia pozostaje miejsce dla nowej organizacji typu NOZ. Model ten mógłby być wdrożony np. w formie spółki celowej uczelni wyższej, co znacznie ułatwiałoby dostęp do ekspertów ze środowiska akademickiego.

\section{Wnioski}

1. Rozwój HB-HTA w Polsce oparty na NOZ odbywałby się w środowisku ogólnie sprzyjającym temu modelowi.

2. Model wdrażania HB-HTA oparty na NOZ miałby ogólnie pozytywny wpływ na polski system ochrony zdrowia, w szczególności zaś na pacjentów, szpitalnictwo i sektor naukowo-badawczy związany z ochroną zdrowia.

3. Wdrażanie HB-HTA w Polsce oparte na NOZ ma korzystne prognozy i szanse wdrożenia oraz rozwoju.

\section{Przypisy}

${ }^{1}$ Przyjmuje się w niniejszym opracowaniu, że z poziomem strategicznym związane są te miejsca i działania w systemie opieki zdrowotnej oraz państwie, gdzie ustalany jest kształt jednostek organizacyjnych będących wykonawcami polityki zdrowotnej, definiowane są zasady odpowiedzialności za zdrowie, określane są priorytetowe cele i zadania lub ustalane są mechanizmy finansowania. Natomiast na poziomie operacyjnym polityki zdrowotnej nadawana jest tej polityce jej realna postać.

${ }^{2}$ Dz.Urz. UE L z dnia 26.06.2014, s. 1.

\section{Piśmiennictwo}

1. O'Rourke B., Oortwijn W., Schuller T., International Joint Task Group. The New Definition of Health Technology Assessment: A Milestone in International Collaboration, „International Journal of Technology Assessment in Health Care" 2020 Jun; 36 (3): 187-190, doi: 10.1017/S0266462320000215. Epub 2020 May 13. PMID: 32398176.

2. Sampietro-Colom L., Lach K., Pasternack I., Wasserfallen J.B., Cicchetti A., Marchetti M., Kidholm K., ArentzHansen H., Rosenmöller M., Wild C., Kahveci R., Ulst M., Guiding Principles for Good Practices in Hospital-Based Health Technology Assessment Units, „International Journal of Technology Assessment in Health Care" 2015; 31 (6): 457-465, doi: 10.1017/S0266462315000732. Epub 2016 Feb 22. PMID: 26899230.

3. Kidholm K., Ølholm A.M., Birk-Olsen M., Cicchetti A., Fure B., Halmesmäki E., Kahveci R., Kiivet R.A., Wasserfallen J.B., Wild C., Sampietro-Colom L., Hospital Managers' Need for Information in Decision-Making: An Interview Study in Nine European Countries, „Health Policy” 2015 Nov; 119 (11): 1424-1432, doi: 10.1016/j.healthpol.2015.08.011. Epub 2015 Aug 24. PMID: 26362086.

4. Grenon X., Pinget C., Wasserfallen J.B., Hospital-Based Health Technology Assessment (HB-HTA): A 10-year Survey at One Unit, ,International Journal of Technology Assessment in Health Care" 2016 Jan; 32 (3): 116-121, doi: 10.1017/S0266462316000258.

5. Poder T.G., Bellemare C.A., Bédard S.K., Fisette J.F., Dagenais P., Impact of Health Technology Assessment Reports on Hospital Decision Makers - 10-year Insight from a Hospital Unit in Sherbrooke, Canada: Impact of Health Technology Assessment on Hospital Decisions, „International Journal of Technology Assessment in Health Care" 2018 Jan; 34 (4): 393-399, doi: 10.1017/S0266462318000405. 
6. Gałązka-Sobotka M., Kowalska-Bobko I., Łach K., Mela A., Furman M., Lipska I., Recommendations for the Implementation of Hospital-Based HTA in Poland: Lessons Learned from International Experience, „Frontiers in Pharmacology” 2021 May 13; 11: 2493, doi: 10.3389/ fphar.2020.594644.

7. Raszewska-Skałecka R., Rola organizacji pozarzadowych $w$ działalności gospodarczej na przykładzie fundacji, ,Ekonomia" 2007; 15.
8. Miłostan N., Szkoła wyższa jako przedsiębiorca $w$ warunkach społecznej gospodarki rynkowej, w: Zarządzanie szkoła wyższa, red. J. Blicharz, A. Chrisidu-Budnik, A. Sus, E-Wydawnictwo. Prawnicza i Ekonomiczna Biblioteka Cyfrowa. Wydział Prawa, Administracji i Ekonomii Uniwersytetu Wrocławskiego, Wrocław 2014.

9. Sobczak A., Struktury organizacyjne, w: Zarzadzanie. Teoria i praktyka, red. A.K. Koźmiński, W. Piotrowski, PWN, Warszawa 2013: 295-296. 